Annals of Warsaw University of Life Sciences - SGGW

Land Reclamation No 44 (2), 2012: 121-132

(Ann. Warsaw Univ. of Life Sci. - SGGW, Land Reclam. 44 (2), 2012)

\title{
The Kolmogorov's microscale eddies in a compound channel
}

\author{
ADAM PAWEŁ KOZIOŁ \\ Department of Hydraulic Engineering, Warsaw University of Life Sciences - SGGW
}

\begin{abstract}
The Kolmogorov's microscale eddies in a compound channel. Investigations of the longitudinal sizes of the smallest eddies (Kolmogorov's microscale) presented in the paper are based on measurements of instantaneous velocities in a hydraulic laboratory in a compound trapezoidal channel with different roughness conditions (smooth bed, rough bed) and with trees system on the floodplains. Sizes of the smallest eddies varied in the ranges of 0.08 to $0.48 \mathrm{~mm}$. The changes of longitudinal sizes of the floodplain microeddies are not caused by: the increase of floodplain roughness, the presence of trees, but only when the main channel bed is smooth, and they are also not caused by the increase of roughness of the main channel sloping banks. However, the increase of the size of the floodplain microeddies is influenced by trees, when the roughness of the floodplains and the main channel sloping banks are identical. The increase of microeddies size in the main channel is influenced by: the increase of the main channel sloping banks roughness, by the presence of trees on the floodplains, but only when the roughness of the floodplains and the main channel sloping banks are identical. Microeddies are larger in the main channel centerline than on the floodplains, and the smallest ones were present in the main channel/floodplain interface. The calculated values of microeddies reached decimal parts of a millimeter, and that is why it is difficult to prove vital changes of their values, caused by bed roughness and floodplain trees influence.
\end{abstract}

Key words: compound channel, microscale, Kolmogorov's eddies, vegetation, floodplains.

\section{INTRODUCTION}

The research on turbulence leads to the knowledge on kinematic and dynamic structure of water stream in a compound channel, and it is also the condition to explain the processes occurring during the flow of water. Turbulent flow is characterized by a chaotic and intensive mixing of water mass in this area, where velocities change their values and directions temporarily. The knowledge on this flow turbulence structure will provide for a proper understanding of processes such as: the exchange of mass and momentum between these parts of the channel that have diversified velocities, the transport capacity of a stream, contaminant transport and the whole cross-sectional discharge capacity. The research on turbulence characteristics is realized both in natural riverbeds and on small-scale physical models of a riverbed. Eddies, both in micro and macro scale, are significant for the analyses of processes occurring during the flow of water. Using the channel model, which is described below, and applying different roughness of the channel without and with vegetated floodplains, the variability 
of macroeddies was previously analyzed in the research papers by: Koziol (2000, 2002), Rowiński et al. (2002), Rowiński and Mazurczyk (2006), Czernuszenko et al. (2007), Mazurczyk (2007a) and Kozioł (2008). Relation between sizes of macroeddies to Kolmogorov's microeddies and Taylor's microeddies ratio from Reynolds's number, was as well given in Mazurczyk (2007a).

This paper presents the analysis of the channel roughness and floodplain trees influence on the longitudinal sizes of the smallest eddies, calculated basing on the measurements of instantaneous, longitudinal water velocities in a compound channel. Instantaneous velocities of water in each direction were measured in a main channel and on floodplains for five tests: smooth channel - Test 1 , the channel with rough floodplains - Test 2 , the channel with rough floodplains with emergent vegetation on the floodplains - Test 3 (Kozioł 2000, Rowiński et al. 2002), channel with rough floodplains and rough sloping banks of the main channel - Test 4 (Czernuszenko et al. 2007), the channel with rough floodplains and rough sloping banks of the main channel with emergent vegetation on the floodplains (Kozioł 2008).

\section{MATERIAL AND METHODS}

The experiments considered herein were carried out in the Hydraulic Laboratory of the Department of Hydraulic Engineering, Faculty of Civil and Environmental Engineering at the Warsaw University of Sciences - SGGW. A straight open channel (16 m long and $2.10 \mathrm{~m}$ wide) with a symmetrically trapezoidal cross-section was used for the laboratory tests. The main channel width was equal to $30 \mathrm{~cm}$ and the floodplains width was $60 \mathrm{~cm}$. The sloping banks were sloping at the ratio $1: 1$. The bed slope of the channel was $0.5 \%$. Water discharge values were recorded with the use of a circular weir $540 \mathrm{~mm}$ in diameter. A row of PCV pipes was installed in the initial channel reach to straighten subside the flow. An uniform and steady flow was used in every case. The water surface was kept parallel to the bed during the experiments. The water surface slope was measured by recording the pressure differences among piezometers located along the centerline of the channel bed at the distances 4 and $12 \mathrm{~m}$ from the channel entrance.

Five tests for two roughness values of floodplains and sloping banks were utilized (Fig. 1 and 2). In the first test (Tests 1), the surface of the main channel bed was smooth (Manning's roughness coefficient $n=0.011 \mathrm{~m}^{-1 / 3} \mathrm{~s}$ ). In Test 2 and 3 the floodplains, in Test 4 and 5 all sloping banks were covered by cement mortar composed with terrazzo with grains of 0.5 to $1 \mathrm{~cm}$ in diameter (Fig. 1 and 2). The Manning's roughness coefficient for the rough surfaces of the floodplain equaled about $n=0.018$ $\mathrm{m}^{-1 / 3} \mathrm{~s}$ for the left and $0.025 \mathrm{~m}^{-1 / 3} \mathrm{~s}$ for the right. The values of average Manning's coefficient and absolute roughness of the channel surface were determined from the Manning's equation and the Colebrook-White's equation on the basis of the average velocity values of the flow measured in those parts of the channel. The obtained roughness amounted to $k_{s}=0.00005 \mathrm{~m}$ for the smooth surfaces, $k_{s}=0.0074 \mathrm{~m}$ for the rough surface of the left floodplain, and $k_{s}=0.0124 \mathrm{~m}$ 


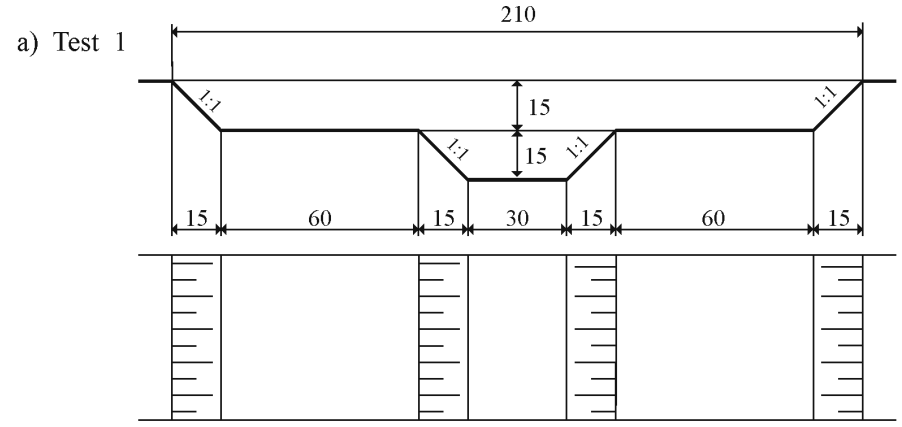

b) Test 2
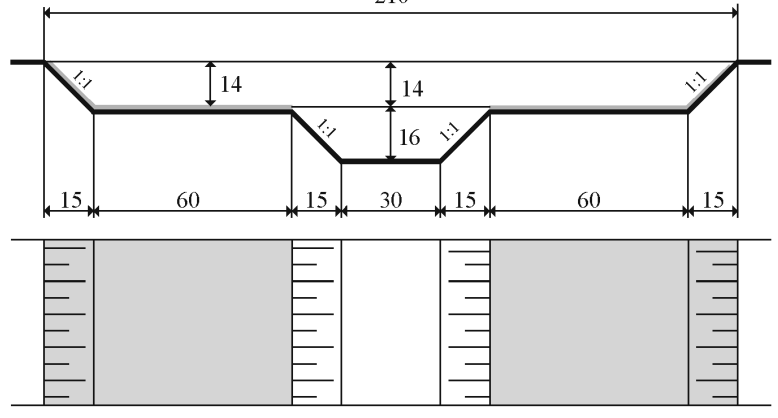

c) Test 3
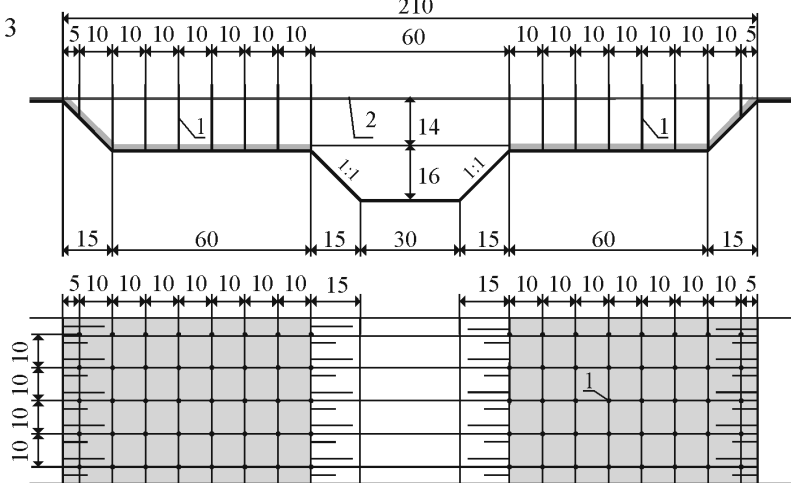

FIGURE 1. Scheme of a laboratory cross-section for three considered tests: a) Test 1 in a channel with the smooth bed, b) Test 2 in a channel with the smooth bed of the main channel and rough floodplains, c) Test 3 in a channel with the smooth bed of the main channel and rough floodplains vegetated with trees $(0.1 \times 0.1 \mathrm{~m}$ trees system), 1 - pipes imitating trees, 2 - wooden strips supporting the trees (dimensions in $\mathrm{cm}$ )

for the rough surface of the right floodplain. In Tests 3 and 5 high vegetation (trees) growing on the floodplains were modeled by aluminum pipes of $0.8 \mathrm{~cm}$ diameter, placed with both longitudinal and lateral spacing's of $10 \mathrm{~cm}$ in Test 3
(Fig. 1c) and $20 \mathrm{~cm}$ in Test 5 (Fig. 2b). There were 16 pipes in Test 3 and 8 pipes in Test 5 in each of 161 cross-sections. The "tree-tops" were emergent and the pipes were not subject to any elastic strains caused by overflowing water. 
a) Test 4

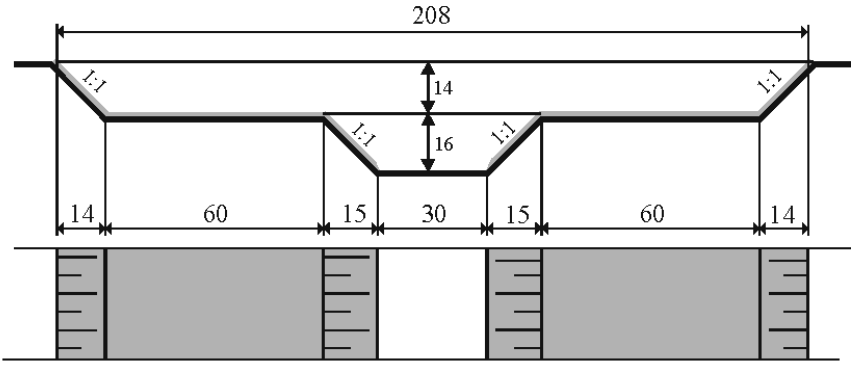

b) Test 5
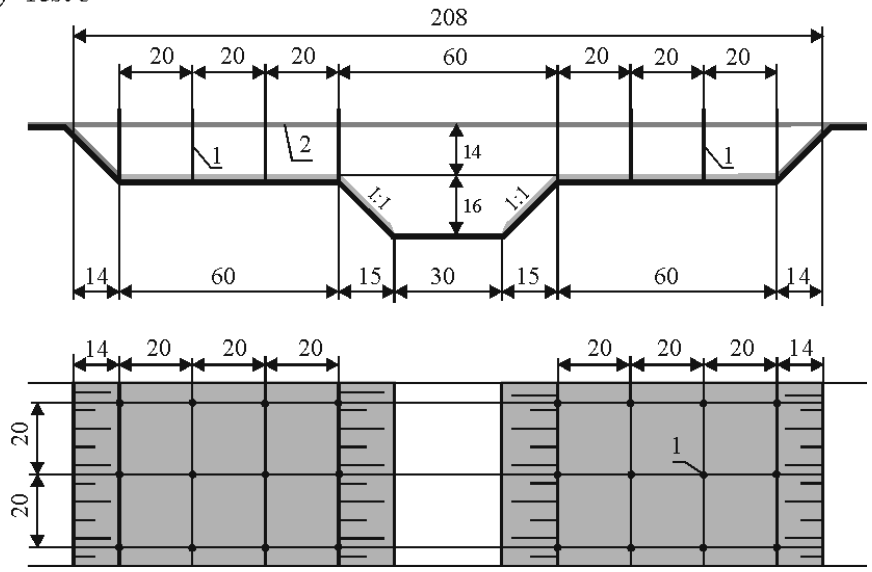

FIGURE 2. Scheme of a laboratory cross-section for two considered tests: a) Test 4 in a channel with the smooth bed of the main channel and rough sloping banks of the main channel, rough floodplains, b) Test 5 in a channel with the smooth bed of the main channel and rough sloping banks of the main channel, rough floodplains vegetated with trees $(0.2 \times 0.2 \mathrm{~m}$ trees system $), 1-$ pipes imitating trees, 2 - wooden strips supporting the trees (dimensions in $\mathrm{cm}$ )

The hydraulic parameters of past studies are given in Table 1. Water levels in the main channel and on the floodplains, velocities, water temperature and water discharge were measured during the course of the experiment. The cross-section at the half of the channel length was selected for velocity measurements (Fig. 3, Fig. 4). Instantaneous longitudinal velocities were measured with two probes. First measurement were conducted at the use of a electromagnetic meter then after the purchase of the new meter mea- surement were continued at the use of a acoustic Doppler velocity meter (ADV).

In Tests 1, 2 and 3 instantaneous longitudinal velocities were measured with the use of the programmable electromagnetic liquid velocity meter manufactured by Delft Hydraulics. The principle of operation of the device is based on Faraday's induction law for a conductive liquid moving through a magnetic field induced by a pulsed current through a small coil inside the body of a special bi-directional, electromagnetic, ellipsoi- 
TABLE 1 . The hydraulic parameters

\begin{tabular}{|c|c|c|c|c|c|}
\hline \multirow{2}{*}{ Parameter } & \multicolumn{5}{|c|}{ Test } \\
\hline & 1 & 2 & 3 & 4 & 5 \\
\hline Discharge $Q[1 / \mathrm{s}]$ & 69.3 & 50.0 & 38.9 & 95.2 & 65.7 \\
\hline Depth in the main channel $H[\mathrm{~cm}]$ & 20.2 & 21.9 & 21.2 & 28.3 & 28.0 \\
\hline Depth in the floodplain $h_{f}[\mathrm{~cm}]$ & 5.2 & 5.9 & 5.2 & 12.3 & 12.0 \\
\hline Relative depth $D r=h_{f} / H$ & 0.26 & 0.27 & 0.24 & 0.43 & 0.43 \\
\hline Vegetation on the floodplains & - & - & Trees & - & Trees \\
\hline The banks slope ratio $[-]$ & \multicolumn{5}{|c|}{$1: 1$} \\
\hline The bed slope i [\%o] & \multicolumn{5}{|c|}{0.5} \\
\hline
\end{tabular}

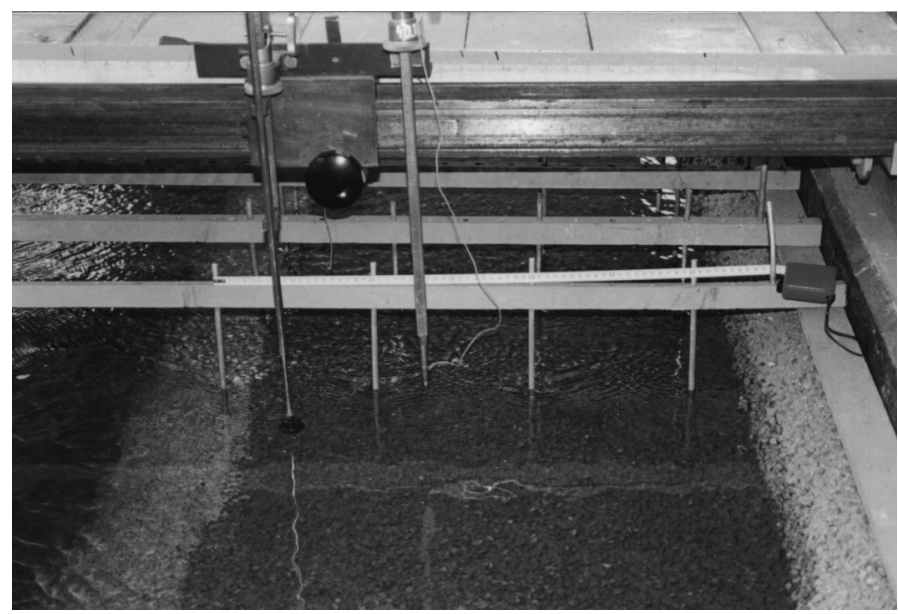

FIGURE 3. The view of the model of the channel for the experiment 5 with pipes imitating the trees

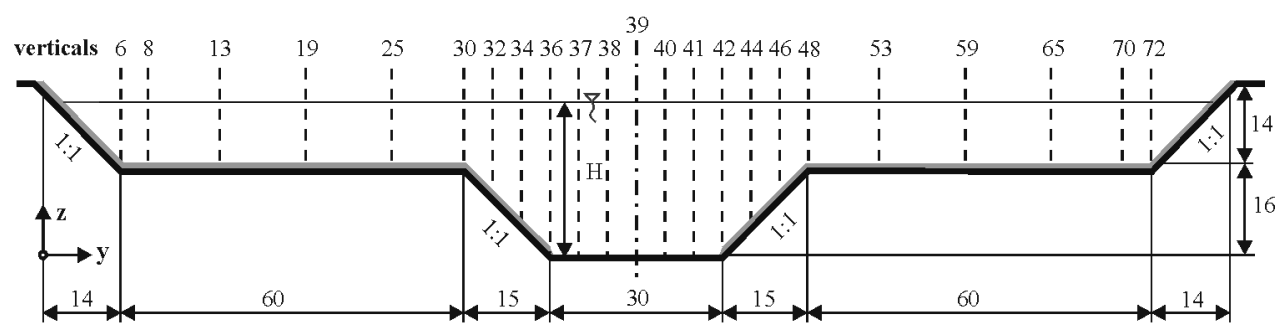

FIGURE 4. Scheme of the experimental cross-section with the arrangement of measuring verticals (dimensions in $\mathrm{cm}$ ) 
dal sensor of the size $11 \times 33 \mathrm{~mm}$. The accuracy of the measurement of velocity is $\pm 0.01 \mathrm{~m} / \mathrm{s}$. The measurements of instantaneous longitudinal velocities were carried out at 48 points at 10 verticals (verticals 6-36 and 39, Fig. 4). The time of velocity recording at each point was roughly $40 \mathrm{~min}$ and the sampling interval of $0.2 \mathrm{~s}$ was taken. It turned out that the time slightly shorter than $27 \mathrm{~min}$ was enough to obtain fully steady statistical characteristics of the flow and therefore the time series of 8000 elements (corresponding to the time period of about $26.7 \mathrm{~min}$ ) were further elaborated. More detailed informations about the methodology are found in the paper Rowiński at al. (2002).

In Tests 4 and 5 instantaneous longitudinal velocities were measured with the use of a three-component acoustic Doppler velocity meter (ADV) manufactured by Sontek Inc. The ADV works on pulse-to-pulse coherent Doppler techniques in relatively high temporal resolution. The ADV proved to yield a good description of the turbulence characteristics when certain conditions related to the flow itself and the configuration of the instrument are satisfied. The measurements were conducted with maximum frequency $25 \mathrm{~Hz}$ in the velocity range of 0 to $1.0 \mathrm{~m} / \mathrm{s}$ with an accuracy of $0.25 \mathrm{~cm} /$ $/ \mathrm{s}$. The measurements of instantaneous velocities were carried out at 250 points at 23 verticals - six on each floodplain and eleven in the main channel (Fig. 4). With a time of velocity recorded in several dozen points was roughly $20 \mathrm{~min}$ and the sampling interval of $0.04 \mathrm{~s}$ was taken, it turned out that a sampling time, it slightly shorter than $6 \mathrm{~min}$ was enough to obtain fully steady statistical charac- teristics of the flow and, therefore, a time series of 9000 elements (corresponding to the time period of about $360 \mathrm{~s}$ ) were used subsequently. More detailed informations about the methodology are found in the paper Czernuszenko at al. (2007).

\section{RESULTS AND DISCUSSION}

\section{The determination of longitudinal mi- croeddies size in the stream}

Size of microeddies (Kolmogorov's microscale) stands for the smallest size of eddies, which are present in the turbulent flow of water. In order to determine the size of microeddies $\eta$, spectrum density function $S(\omega)$ was calculated for instantaneous, longitudinal velocities and next the proper frequency range of velocities was determined, and for that range the rate of energy dissipation $\varepsilon$ was analyzed. Spectrum density function $S(\omega)$ is defined as Fourier-transformed autocorrelation function. Then, for a selected velocity component, following equation can be written (Czernuszenko and Lebiecki 1989):

$$
S(\omega)=\frac{1}{\pi} \int_{0}^{\infty} \cos (\omega, t) R(t) d t
$$

where $R(t)$ is the autocorrelation function of instantaneous longitudinal velocities, $\omega=2 \pi f-$ is the angular frequency, $t$ - time.

Spectrum density function $S(\omega)$ expresses kinetic energy of eddies for the frequency range $(\omega, \omega+\mathrm{d} \omega)$ and this function is not uniform versus frequency. Exemplary spectrum density functions 
for the courses of instantaneous longitudinal velocities are given in Figure 5, and for both probes they are very similar. These functions take the highest values for the frequencies of the averaged motion, while the lowest values are reached for the highest frequencies.

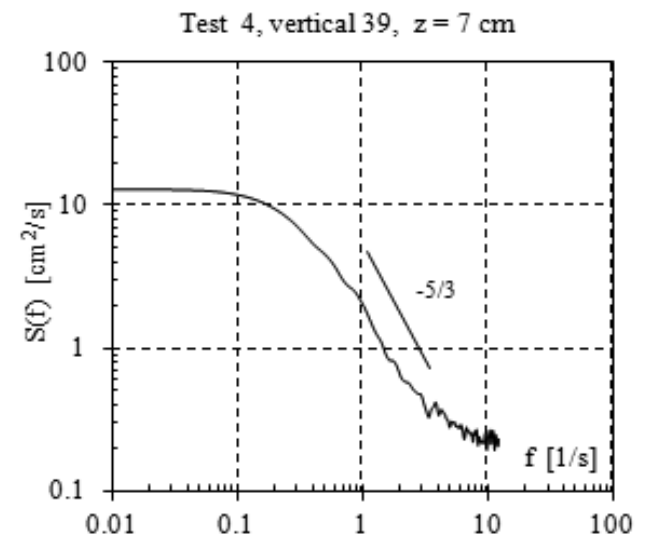

be distinguished such subarea, in which the energy is neither taken from the average flow, nor dissipated into heat, but is transported towards smaller turbulent structures. Such subarea is called the inertial area of a constant energy stream, coming from all scales of eddies: from

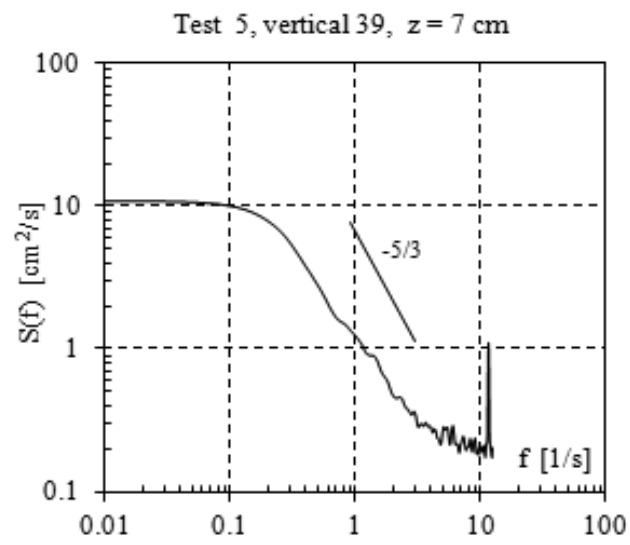

FIGURE 5. Frequency spectra $S(f)$ of instantaneous longitudinal velocities $(z-$ distance from the measurement point to the bed surface)

The analysis of spectrum density function involves, among others, the determination of frequency range (inertial range), whose existence is assumed by Kolmogorov's hypothesis, and where the local anisotropy hypothesis is also valid as well as $-5 / 3$ power law (Nikora 1999). According to theory by Kolmogorov, within the energy spectrum, an area of a universal equilibrium can be distinguished, and this area covers in a large extent the dissipative area, where final conversion of kinetic energy into heat takes place under the influence of liquid viscosity, and where the form of $S(\omega)$ function is only influenced by viscosity $v$ and dissipation $\varepsilon$. For higher Reynolds's numbers, at the beginning of the universal equilibrium area, there can the largest eddies to the smallest ones. The determination of such areas enables to find turbulence scales and energy dissipation rates. Above mentioned values can be calculated by applying following formulas (Nikora et al. 1994):

$$
S(\omega)=C_{1} \varepsilon^{2 / 3} V^{2 / 3}(\omega)^{-5 / 3}
$$

$\eta=\left(\frac{v^{3}}{\varepsilon}\right)^{1 / 4}$

where: $C_{1}=0.48-$ constant (Monin and Yaglom 1975), $\eta$ - size of microeddies (Kolmogorov's microscale), $V$ - mean velocity, $v$ - molecular (kinematic) viscosity. Equations (2) and (3) are valid, 
on condition that we apply the hypothesis of Taylor, which considers frozen turbulence. Equation (2), known as the Kolmogorov's power law $-5 / 3$, is used to determine energy dissipation rates in an inertial area. The rates of energy dissipation were calculated as arithmetical means, derived from the course of a spectrum function for a particular area. Knowing the energy dissipation rates, the sizes of Kolmogorov's microeddies $\eta$ were calculated by applying equation (3). The calculated values of microeddies are comparable for two different probes.

\section{Results of the Kolmogorov's microscale eddies for non-vegetated floodplains}

Figure 6 presents vertical distribution of longitudinal velocities and longitudinal sizes of microeddies $\eta$ (Kolmogorov's microscale) in Tests 1,2 and 4 ( $z=$ distance from the bed, $h=$ depth in a vertical). The calculated values of microeddies are very small in comparison to the value of the velocity (Fig. 6) and to the length of macroeddies $L$ which most of- ten are presented in relation to the water depth (0.4-4.4 L/h, Rowiński et al. 2002, and 0.2-1 L/h, Czernuszenko et al. 2007). All calculated sizes of microeddies are in the order of decimal parts of a millimeter, and they vary from 0.013 to $0.044 \mathrm{~cm}$. Both for the smooth and the rough floodplain (Tests 1 and 2) they vary from 0.013 to $0.020 \mathrm{~cm}$ and in Test 4 from 0.015 to $0.027 \mathrm{~cm}$. In Tests 1 and 2 , microeddies do not vary significantly in the main channel, and they range from 0.014 to $0.031 \mathrm{~cm}$, while the increase of sloping banks roughness in Test 4 resulted in such growth of microeddies size, that they reached from 0.024 to $0.044 \mathrm{~cm}$ in length (Fig. 6).

It was concluded, that the increase of floodplain roughness and main channel sloping banks roughness, did not cause vital changes of microeddies size on the floodplain. However, the increase of floodplain roughness and the increase of main channel sloping banks roughness caused a growth of microeddies size in the main channel (Fig. 6).
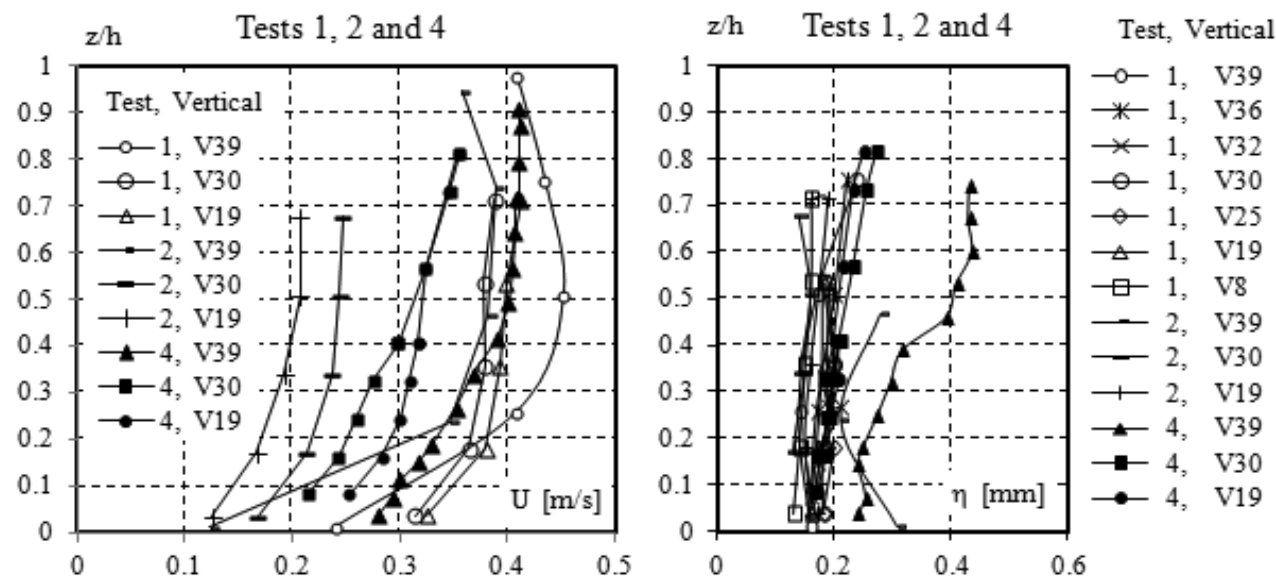

FIGURE 6. Vertical distribution of longitudinal velocities and longitudinal sizes of the smallest eddies in Tests 1,2 and 4 


\section{Results of the Kolmogorov's microscale eddies with emergent vegetation on the floodplains}

Figures 7 and 8 present vertical distributions of longitudinal velocities and longitudinal sizes of Kolmogorov's microeddies $\eta$ in the compound channel with the presence of floodplain trees (Tests 3 and 5). Trees did not result in big changes of microeddies size, and the calculated values are also in the order of decimal parts of a milimeter and range from 0.008 to $0.048 \mathrm{~cm}$ (Fig. 7 and 8 ). In Test 3 , microeddies size did not change on the floodplain and in the main channel, but only in the interaction zone, close to the surface that divides the main channel and the floodplain, the eddies were decreased (vertical 30, Fig. 7).

In Test 5, floodplain trees contributed to $50 \%$ increase of microeddies size on floodplains, but did not have an influence on the vertical distribution of microeddies length (Fig. 7). However, in the surface dividing the main channel and the floodplain, microeddies length did not vary considerably, and in the test with floodplain trees, the lengths of microeddies did not change with depth. That is why the microeddies size slightly increased near the bed, and in Test 5 , over the relative depth $0.4 z / h$, they decreased. The size of microeddies in the main channel almost did not change in Test 5, but floodplain trees resulted in changes of the vertical distribution of microeddies size. With the increasing distance from the bed, the length of microeddies increases until the depth of $0.45 \mathrm{z} / \mathrm{h}$, at which the eddies are the longest, and then the lengths decrease upwards to the surface of water (Fig. 8). The lengths of microeddies are significantly higher in the middle zone of the main channel $(0.3-0.7 \mathrm{z} / \mathrm{h})$ than on the floodplain.

The calculated Kolmogorov's microeddies reached very similar values to those achieved in a Braunschweig experimental channel (Mazurczyk 2007a, Mazurczyk 2007b), both in the main channel and on the floodplains. It was then concluded, that trees on the floodplains
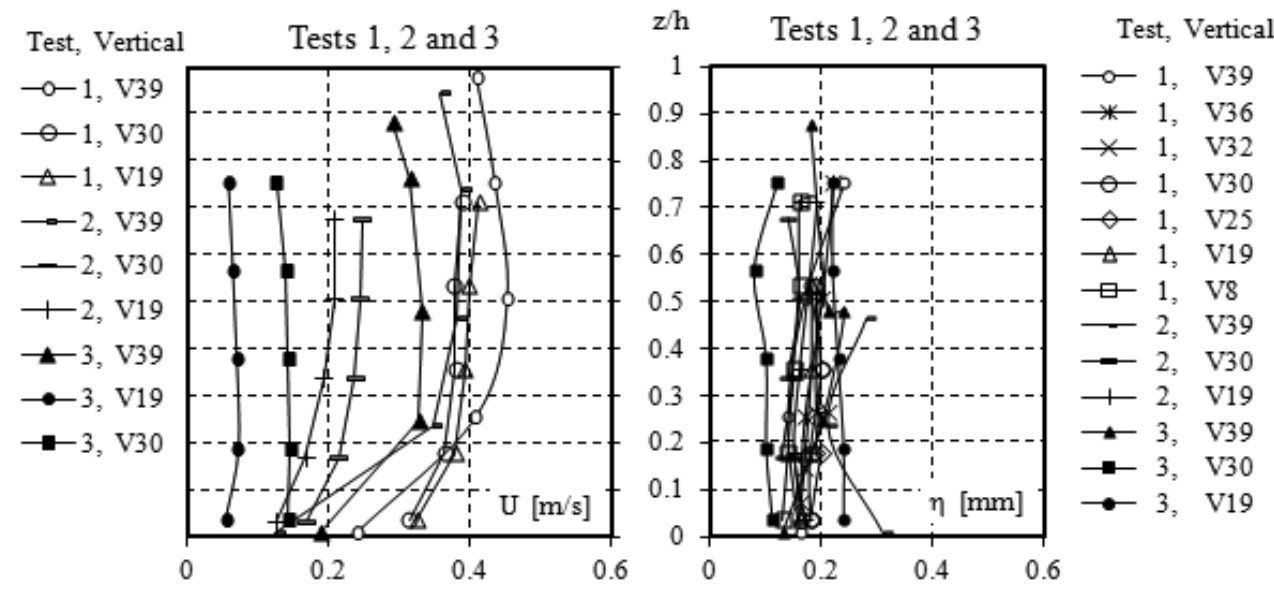

FIGURE 7. Distribution of longitudinal velocities and longitudinal sizes of the smallest eddies in Tests 1,2 and 3 

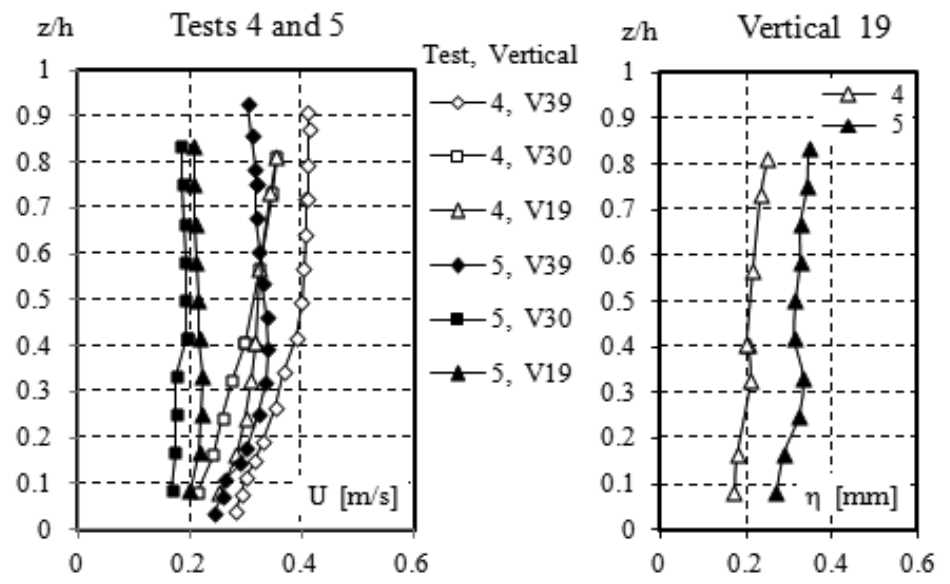

Vertical 30
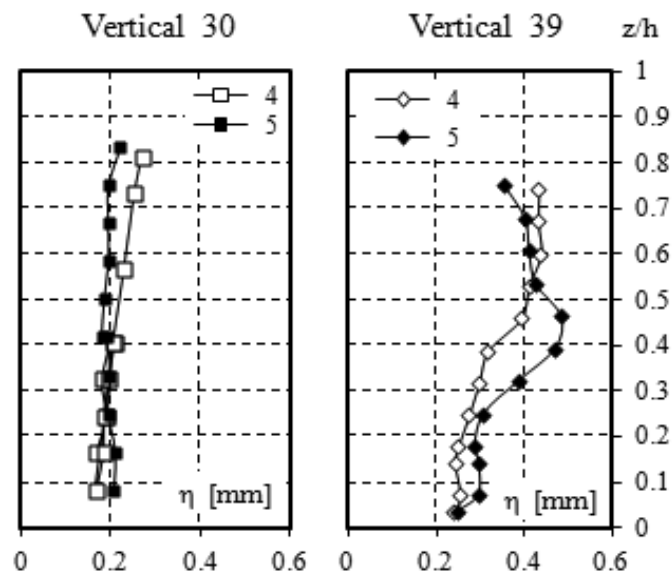

FIGURE 8. Distribution of longitudinal velocities and longitudinal sizes of the smallest eddies in Tests 4 and 5

did not result in considerable changes of microeddies length, and usually their values were very similar. The analyzed microscale was within the range: 0.01 to $1 \mathrm{~cm}$. This statement is consistent with the scientific results achieved for free streams and near the wall regions (Czernuszenko and Lebiecki 1989, Nikora et al. 1994, Nikora and Smart 1997).

\section{CONCLUSION}

Investigations of the longitudinal sizes of the smallest eddies (Kolmogorov's microscale) presented in the paper are based on measurements of instantaneous velocities in a hydraulic laboratory in a compound trapezoidal channel with different roughness conditions (smooth 
bed, rough bed) and with trees system on the floodplains. The calculated values of microeddies are comparable for two different probes and sizes of the microeddies varied in the ranges of 0.08 to 0.48 $\mathrm{mm}$.

The changes of longitudinal sizes of the smallest eddies on the floodplains are not influenced by: the increase of floodplain roughness (Test 2), the presence of trees, but only when the surface of the main channel is smooth (Test 3 ), the increase of main channel sloping banks roughness (Test 4). However, approximately $50 \%$ increase of microeddies length on the floodplain is conditioned by trees, but only when the roughness of the floodplains and sloping banks of the main channel are identical (Test 5).

The increase of the longitudinal sizes of the smallest eddies in the main channel is caused by: the increase of the main channel sloping banks roughness (Test 4), the presence of floodplain trees, but only when the roughness of the floodplain and the main channel are identical.

The longitudinal sizes of the smallest eddies are greater in the centerline of the main channel than on the floodplains, however, the smallest are in the main channel/floodplain interface.

The calculated longitudinal sizes of microeddies are very small in comparison to the value of the velocity $(0.1-0.45$ $\mathrm{m} / \mathrm{s}$ ) and to the length of macroeddies which most often are presented in relation to the water depth $(0.4-4.4 \mathrm{~L} / \mathrm{h}$, Rowiński et al. 2002). The values of the microeddies are in the order of decimal parts of a millimeter, and that is why it is difficult to conclude significant changes of their values, as a result of bed roughness and floodplain trees influence.

\section{REFERENCES}

CZERNUSZENKO W., LEBIECKI P. 1989: "Turbulencja w przepływach rzecznych" [The turbulence in river-flows]. Archiwum Hydrotechniki Vol. 36 (1-2), 17-34 [Engl. summ.].

CZERNUSZENKO W., KOZIOZ A., ROWIŃSKI P.M. 2007: Measurements of 3D Turbulence Structure in a Compound Channel. Archives of Hydro-Engineering and Environmental Mechanics, Institute of Hydro-Engineering PAS 54 (1), 3-21.

KOZIOŁ A. 2000: Rozmiary podłużnych makrowirów w korycie o złożonym przekroju poprzecznym [Longitudinal sizes of the largest eddies in the compound channel]. Przeglad Naukowy Wydziatu Inżynierii $i$ Ksztattowania Środowiska 18, 151-159 [Engl. summ.].

KOZIOŁ A. 2002: Mikrowiry Kołmogorowa w korycie o złożonym przekroju poprzecznym [The Kolmogorov microscale in the compound channel]. Wiadomości Instytutu Meteorologii i Gospodarki Wodnej Vol. XXV (XLVI), 1, 37-42 [Engl. summ.].

KOZIOŁ A. 2008: Badanie czasowej i przestrzennej makroskali turbulencji w korycie o złożonym przekroju poprzecznym [Investigation of the time and spatial macroscale of turbulence in a compound channel]. Acta Scientiarum Polonorum Architectura 7 (4), 15-23 [Engl. summ.].

MAZURCZYK A. 2007a: Scales of turbulence in compound channels with trees on floodplains. Publs. Inst. Geophys. Pol. Acad. Sci. Monographic Vol. E-6 (390).

MAZURCZYK A. 2007b: Pola prędkości turbulentnych w kanałach o złożonych przekrojach poprzecznych $\mathrm{z}$ drzewami [Turbulent velocity fields in channels with compound cross-sections with trees]. $\mathrm{PhD}$ Thesis. Institute of Geophysics, Polish Academy of Sciences [Engl. abs.].

MONIN A.S., YAGLOM A.M. 1975: Statistical fluid mechanics: mechanics of turbulence. Vol. 2. MIT Press, Cambridge, Mass. 
NIKORA V.I. 1999: Origin of the "-1" spectral law in wall-bounded turbulence. Physical Review Letters Vol. 83, 4, 734-736.

NIKORA V.I., ROWIŃSKI P., SUKHODOLOV A., KRASUSKI D. 1994: Structure of river turbulence behind warmwater discharge. Journal of Hydraulic Engineering 120 (2), 191-208.

NIKORA V.I., SMART G.M. 1997: Turbulence characteristics of New Zealand gravel-bed rivers. Journal of Hydraulic Engineering 123 (9), 764-773.

ROWIŃSKI P.M., CZERNUSZENKO W., KOZIOŁ A.P., KUBRAK J. 2002: Properties of streamwise turbulent flow filed in an open two-stage channel. Archives of Hydro-Engineering and Environmental Mechanics 49 (2), 37-57.

ROWIŃSKI P.M., MAZURCZYK A. 2006: Turbulent characteristics of flows through emergent vegetation. Proceedings of River Flow, Lisbon, Portugal, 623-630.

Streszczenie: Mikrowiry Kolmogorowa w korycie o złożonym przekroju poprzecznym. W artykule przedstawiono długości podłużnych mikrowirów (mikroskala Kołmogorowa) w strumieniu w korycie o złożonym przekroju poprzecznym. Długości mikrowirów obliczono na podstawie szybkości dyssypacji energii i lepkości cieczy. Do określenia szybkości dyssypacji wykorzystano analizę funkcji gęstości spektralnej, wyznaczonej na podstawie pomierzonych w laboratorium hydraulicznym chwilowych prędkości w korycie o złożonym przekroju poprzecznym dla dwóch różnych szorstkości powierzchni dna koryta i rozmiesz- czonych drzew na przyległych terenach zalewowych. Na zmiany podłużnych długości mikrowirów na terenie zalewowym nie wpływa: wzrost chropowatości powierzchni terenów zalewowych, występowanie drzew ale kiedy powierzchnia koryta głównego jest gładka, wzrost chropowatości powierzchni skarp koryta głównego. Natomiast na wzrost długości mikrowirów na terenie zalewowym wpływają drzewa kiedy powierzchnie terenów zalewowych i skarp koryta głównego są identyczne. Na wzrost długości mikrowirów w korycie głównym wpływa: wzrost chropowatości powierzchni skarp koryta głównego, występowanie drzew na terenach zalewowych ale kiedy powierzchnie terenów zalewowych i skarp koryta głównego są identyczne. Mikrowiry są większe w osi symetrii koryta głównego niż na terenach zalewowych, a najmniejsze w płaszczyźnie rozdziału pomiędzy obiema częściami koryta. Obliczone wartości mikrowirów są rzędu dziesiątych części milimetra, więc trudno mówić o istotnych zmianach wartości w wyniku wpływu chropowatość powierzchni dna i obecności drzew na terenach zalewowych.

Słowa kluczowe: koryto o złożonym przekroju poprzecznym, mikroskala, mikrowiry Kołmogorowa, roślinność, tereny zalewowe.

MS. received November 2012
Autor's address:
Adam P. Kozioł
Katedra Inżynierii Wodnej
Szkoła Główna Gospodarstwa Wiejskiego
ul. Nowoursynowska 166, 02-787 Warszawa
Poland
e-mail: adam_koziol@sggw.pl 